IZA DP No. 6782

Firm Insurance and Sickness Absence of Employees

Niels Westergård-Nielsen

Filip Pertold

August 2012

Forschungsinstitut zur Zukunft der Arbeit Institute for the Study of Labor 


\title{
Firm Insurance and Sickness Absence of Employees
}

\author{
Niels Westergård-Nielsen \\ Aarhus University \\ and IZA \\ Filip Pertold \\ Aarhus University \\ Discussion Paper No. 6782 \\ August 2012 \\ IZA \\ P.O. Box 7240 \\ 53072 Bonn \\ Germany \\ Phone: +49-228-3894-0 \\ Fax: +49-228-3894-180 \\ E-mail: iza@iza.org
}

\begin{abstract}
Any opinions expressed here are those of the author(s) and not those of IZA. Research published in this series may include views on policy, but the institute itself takes no institutional policy positions.

The Institute for the Study of Labor (IZA) in Bonn is a local and virtual international research center and a place of communication between science, politics and business. IZA is an independent nonprofit organization supported by Deutsche Post Foundation. The center is associated with the University of Bonn and offers a stimulating research environment through its international network, workshops and conferences, data service, project support, research visits and doctoral program. IZA engages in (i) original and internationally competitive research in all fields of labor economics, (ii) development of policy concepts, and (iii) dissemination of research results and concepts to the interested public.
\end{abstract}

IZA Discussion Papers often represent preliminary work and are circulated to encourage discussion. Citation of such a paper should account for its provisional character. A revised version may be available directly from the author. 


\section{ABSTRACT}

\section{Firm Insurance and Sickness Absence of Employees*}

We investigate the effect of firms' participation in an insurance scheme on the long-term sickness absence of their employees, using administrative records. In Denmark and several other European countries, firms are obliged to cover the first two weeks of sickness. The insurance scheme is provided by government authority and is designed to help small firms with the financial burden related to sickness absence of their workers. We use an exogenously-set threshold for the eligibility as a policy experiment. Using regression discontinuity in the fuzzy form, we show that sickness absence in insured firms is much more prevalent than in uninsured firms. Sickness spells in insured firms are shorter and the conditional probability to return back to work from sickness is much higher in insured firms. These results suggest that employees in insured firms are less monitored during the first two weeks and that their sickness is less serious. We demonstrate in the paper that the minimum cost of the present insurance scheme is similar to about 1100 man-years. On top of that comes a substantial cost to more short time sickness.

JEL Classification: $\quad$ I12, J28

Keywords: $\quad$ sickness absence, moral hazard, insurance for employers

Corresponding author:

Filip Pertold

Aarhus School of Business

Aarhus University

Department of Economics

Hermodsvej 22

8230 Aabyhøj

Denmark

E-mail: filipp@asb.dk

\footnotetext{
* This research has been financed by a grant from the Norwegian Research Council. Without that the research had not been done. We thank for comments from Harald Dale-Olsen, Paul Bingley and Tor Eriksson. We also thank Simon Bodilsen, who has supplied excellent research assistance.
} 


\section{Introduction}

Sickness absence brings high costs to the society and to the entire economy through the loss of working hours and production. Vast empirical evidence in the economic literature suggests that higher income replacement in sickness spells increases the absence rate. This is also in line with basic economic theory within the standard work-leisure framework (Brown and Session, 1996).

In this paper, we look at the problem of incentives and sickness absence from a different perspective than the traditional literature, which studies incentives and moral hazard mainly on the side of employees, but providing only little evidence about the potential moral hazard on the side of firms. This is surprising given the fact that many policies are actually targeted towards firms rather than workers. Denmark provides an example of such policies, where companies are generally obliged to compensate the loss in income of their workers during the first two weeks of sickness absence.

Literature provides convincing evidence that changes in economic incentives at individual level bring substantial changes in individual sickness absence. The most extensive and up-to-date empirical analysis of absenteeism is provided in Markussen et al. (2011). They show that even after controlling for all possible personal observables, financial incentives still matter. Previous literature is summarized in Ziebarth (2009).

Surprisingly, there is only little evidence about effects of firms' incentives on sickness absence of employees. One particular paper is directly related to our topic. Böheim and Leoni (2011) are looking at the reform in Austria, where the subsidization scheme for small firms was changed and they found significant effects on sickness absence of workers. We provide additional evidence on this topic from a different institutional setting and using precise administrative spell data combined with socio-economic data. We also include duration analysis and identify the presence of moral hazard using a Cox proportional hazard model.

In particular, we examine the effect of the sickness insurance scheme in Denmark, which is provided by public authority as a financial support for small companies. This insurance scheme works the following way. Small employers may insure themselves against the risk of paying wage 
compensation of absence due to sickness by paying a premium to the insurance scheme run by the public authority. The premium is not experience related and is by law $0.69 \%$ of the total yearly wage bill. If the firm is insured, part of the wage costs related to the first two weeks of sickness is reimbursed by the authority.

The main goal of this paper is to test the presence of moral hazard in insured firms. Insured firms have lower incentives to monitor their employees, as they do not cover the total wage costs related to the sickness absence of their employees. At the same time, participation in the sickness insurance scheme is profitable only for firms with a higher prevalence of sickness. We disentangle the adverse selection and moral hazard and show that they both play an important role in explaining the sickness gap between insured and uninsured firms.

To identify the moral hazard, we use a fuzzy discontinuity design created by the eligibility threshold, in order to identify the true causal effect of sickness insurance on sickness absence of workers. We use the eligibility criterion as an instrument for the participation in the insurance scheme. We perform local linear regressions with bandwidth around the eligibility threshold and confirm the presence of moral hazard in insured firms.

Important evidence supporting the moral hazard hypothesis is the opposite relationship between incidence of sickness absence and length of spells. Although insured firms have a much higher incidence of long-term sickness absence, these long-term sickness spells are much shorter than in uninsured firms. This suggests that the composition of sick workers suffering from long-term sickness is different and that sick workers in insured firms suffer from much less serious sickness.

We also provide evidence that firms with specific characteristics sort themselves into the insurance scheme. For example, construction and manufacturing are dominant industries among insured firms. This is consistent with a hypothesis that firms with higher risk of sickness are more likely to enter the insurance scheme. However, even after controlling for this sorting, the differences in sickness absence persist. 


\section{Insurance Scheme in Denmark and Data Description}

Denmark has a comprehensive system of health insurance and sickness benefits where the health insurance is basically free and includes all treatments at GPs and hospitals. All employed and unemployed citizens are also eligible to receive a daily compensation for each day they are not working due to sickness.

In the period 1999-2002, an employer had to pay full wage during the first 2 weeks of sickness. However, small employers may partly insure themselves against this risk by paying a premium. They get reimbursed for the wage expenses related to the first two weeks of sickness up to the maximum unemployment benefit rate.

The condition for participation in this insurance program is that the wage sum of the employer is below 1750 times the maximum weekly benefit. This is similar to the wage sum of about 30 full time low-wage workers or about 20 employees with mixed salaries. An employer will be expelled from the insurance if his wage sum increases above 2160 times the maximum weekly benefit or if his wage sum for 3 consecutive years is above the eligibility level. The premium is not experience related and is by law defined to $0.69 \%$ of the total wage bill.

The sickness absence system also distinguishes between different types of sickness absence and different types of employees. For example, if an employee has worked less than 8 weeks for the current employer or has worked less than 74 hours, the employer does not have to pay the worker from the first day of sickness. Instead, the sick person receives sickness benefits from the municipality from the first day of the spell of sickness. Furthermore, workers with a chronic disease can make an arrangement with the municipality about receiving sickness benefits from the municipality from day one. Similarly, sickness benefits are paid in a number of other cases identified in the data: pregnancy, leave for parents after childbirth, father's leave, work accidents, long-term sickness of children etc. Spells related to short-term employment, chronic diseases, pregnancy, parental leave, work accidence and children sickness are excluded from our current analysis. 
Our data are from administrative records including spells, which are covered by the public insurance scheme. Thus we observe complete spells for insured firms and spells longer than 2 weeks for uninsured firms. We restrict our data to spells longer than 2 weeks, so that we observe comparable spells for both groups. We merge the sickness spells with the socio-economic data using common identifiers for each individual. For the purpose of this draft of the paper, we use sickness records from the years 1999-2002 and for individuals who did not change employer during one calendar year. In total we use 6.2 million person-year observations. Each year it corresponds to about 1.3 millions of private sector workers, and 0.5 millions of sickness spells with an average length of approximately 130 days.

We provide a more detailed description of selected variables in section 5 , in which we compare insured and uninsured firms.

\section{Selection into the Insurance Scheme and Identifying the Moral Hazard}

The formal rule requires that a firm may insure against the sickness of workers if their total wage bill is below an exogenously defined threshold. If a firm is eligible the decision to insure should depend on two key factors - the amount of expected sickness absence and, indirectly, the average wage in a firm. Using formulas for reimbursement and the size of the insurance premium, we find that the participation in the insurance scheme is profitable only, if the total amount of sickness hours (up to 2 weeks after which the authority takes over the main part of the bill) is at least $0.76 \%$ of all working days of a firm ${ }^{1}$. After the second week of sickness absence, a firm need not be insured as it is reimbursed automatically from the municipality. The role of wage expenses is less straightforward. The relationship between the average wage and incentives to insure is driven by the rule that the maximum refunded wage is capped by the maximum unemployment benefit. Therefore, the higher the wages, the lower the proportion of the paid wage during sickness is reimbursed. Consequently, the potential from insurance is relatively smaller compared to the total expenditure related to

\footnotetext{
${ }^{1}$ Cost-benefit analysis is provided in the Annex
} 
sickness. In our analysis we thus control for the individual wages, although we are aware of potential endogeneity. Including wages into the regression, however, does not change our results.

The cost-benefit analysis predicts that firms with workers with a higher risk of sickness are supposed to be more motivated to participate in the scheme. On the other hand, firms should not make the decision to participate based on the expected incidence of long-term sickness or injuries, because work absence longer than 14 days is funded for all firms regardless of the insurance status. The selection mechanism on the workers' should be also negative. More workers should prefer employment in insured firms with lower costs related to sickness absence.

In order to reveal the causal impact of the insurance scheme in sickness absence, we need to employ a proper identification strategy which separates moral hazard behavior from adverse selection of firms and workers into insurance schemes.

In principal, we address this problem using a fuzzy discontinuity that is created by the eligibility criteria. Comparing insured firms and non-insured eligible firms can result in biased estimates. We thus include into the estimation the non-eligible firms that are just marginally bigger (according to their wage bill) than eligible firms. The similarity should result from various random shocks which potentially affect the total wage bill. The second source of exogeneity is the changes in the eligibility threshold set by central authority every year. Eligibility due to these reasons is to be orthogonal to sickness absence in firm, but, at the same time, should predict insurance. We test the validity of this exclusion restriction later. In figure 2 we document the sharp drop in probability to be insured around the eligibility threshold. We observe few firms that are insured even with a substantially bigger total wage bill than the eligibility threshold. We explain this fact by certain administrative delays and errors in the data, so we do not include these firms in our estimation.

Following Lee and Lemieux (2009), we estimate the effect of insurance using an instrumental variable technique. The two stage model uses eligibility as an instrumental variable for the insurance status of the firm. Formally, we estimate our model with the following two stage model.

$$
Y=\alpha+\beta D+f(W-c)+\gamma X+\varepsilon
$$




$$
D=\delta+\tau T+f(W-c)+\lambda X+\mu
$$

where $\mathrm{Y}$ is a propensity of sickness absence, $\mathrm{D}$ is a treatment dummy - being employed in an insured firm, $\mathrm{W}$ is a total wage bill, $\mathrm{c}$ is an eligibility threshold, $\mathrm{T}$ is identifying eligible firms for insurance, $X$ is a vector of all individual and firm level characteristics. The individual characteristics are age, gender, wage, occupation, children, spouse, and educational attainment. The firm level characteristics are regions and industry. Descriptive statistics are provided in the next section.

The treatment effect is consistently estimated if dummy variable $T$ is properly excluded from the first stage equation. In other words, the assignment of firms around the eligibility threshold should be conditional on $\mathrm{X}$ orthogonal to the main outcome variable - sickness absence. In practice, this assumption means firms with a potentially high sickness rate are not supposed to manipulate their total wage bill, so that they are just marginally eligible for the insurance scheme. Furthermore, sick workers do not sort intentionally into firms just eligible for the insurance scheme.

We support these assumptions in several ways. First, we show that there is no clustering in the distribution of firms just below the eligibility threshold. This is shown in figure 1, where we plot the distribution of firms across the total wage bill. Second, we also present a test of validity of our estimator using the method presented in Battistin and Rettore (2008). They propose that the selection bias, which is present in the raw comparison of outcomes of participants and eligible nonparticipants, can be diminished by employing non-participants who are not eligible and are just above the eligibility threshold. In particular, we test the equality of the sickness absence for ineligible and eligible non-participants conditional on our control variables, and we cannot reject null hypotheses using the local linear regression model. This means that we can identify the mean impact on participants in the bandwidth around the eligibility threshold.

Second, we support our assumption that potentially sick workers do not sort into insured firms in our duration analysis. Here, we test whether workers in insured and uninsured firms return from sickness with different conditional probability. Using the Cox proportional hazard model, we show that the hazard ratio of returning back to work for sick workers employed in insured firms is 
$25 \%$ higher compared to sick workers in uninsured firms. This goes against the adverse selection hypothesis suggesting that workers with a high sickness rate would select themselves into insured firms. Johansson and Palme (2004) suggest that if there is there is any sorting effect due to a lower replacement ratio (in our case it is a more favorable condition for sickness) during sickness, one should observe together with a lower prevalence of sickness also shorter sickness spells. And this is clearly not the case in our situation, where workers in insured firms tend to return back to work with a much higher conditional probability.

In the next section we summarize the main differences across insured and insured firms.

\section{Insured versus Uninsured Firms: Main Differences}

Given that a firm must be first eligible to become insured, we divide our data into three groups according to the eligibility criteria which is the total wage bill. Workers are employed either in eligible or non-eligible firms. Within eligible firms we distinguish between insured and uninsured firms. By comparing eligible vs. non-eligible groups, we mainly see differences driven by the total wage bill. On average, non-eligible firms are more than 100 times bigger than eligible firms. Size also drives other differences that we describe in this section. For instance, bigger firms tend to pay more and employ more educated workers. In total, insured firms constitute approximately $30 \%$ of total firms and $13.6 \%$ of the total employment.

Our outcome variables differ substantially across different groups. On average, incidence of sickness is five times higher in insured firms compared to uninsured eligible firms ( 2 versus 10 percent). The sickness absence in non-eligible firms is about 6 percent. Duration of sickness is substantially higher among insured firms than uninsured, which indicates the presence of moral hazard. In the next section we decompose these differences into selection and causal part.

To shed more light on the selection process, we compare a sample of insured and uninsured firms within group of eligible firms. It shows that the main difference between these two groups is in their industrial composition. In particular, the construction industry is overrepresented among 
insured firms. They constitute about $23 \%$ of insured eligible firms, compared to $7 \%$ among uninsured eligible firms.

Overrepresentation of insured firms in construction can be explained by various factors, including higher health risks, which is in line with our model suggesting that insurance is more profitable for firms with a higher risk of sickness. On the other hand, we found relatively small differences in occupational structure between insured and uninsured, but eligible firms.

In terms of demographic characteristics, we observe some statistically significant differences, but the size is not always economically important. For example, workers in insured firms are only one year older than workers in uninsured workers. However, there are some important differences in average educational attainment. First, there are twice as many workers with higher education in uninsured firms. Second, less educated workers are rather sorted into insured firms. Interestingly, we observe counter intuitive differences in the average wage. Workers in insured firms earn $6.5 \%$ more, and this difference is significant. We test for the presence of a pay gap in the regression analysis, and we find that all the differences are explained by a different industrial composition between these groups.

In general, the comparison of insured and uninsured firms shows negative sorting of firms, namely from specific industries that tend to have a higher risk of injuries. Differences due to workers selection due to different educational structure plays a lesser role.. Firm sorting is in line with our cost-benefit analysis, which predicts that firms with a higher risk of sickness are more likely to participate in the insurance scheme.

In our estimation, we use a fuzzy regression discontinuity design. For that purpose we only use firms that are around the eligibility threshold. We thus provide a comparison of insured, uninsured eligible and uninsured non-eligible in table 4. It is clear that we do not observe any significant differences between non-eligible and uninsured eligible firms. This is also confirmed in the regression analysis, which validates our identification strategy. 
Further, in figure 2 we show how selected demographic characteristics change for firms around the eligibility margin. We present the share of females and the share of employees with children in comparison with the share of insured firms in different wage bill groups. It is clear that these two controls do not change discontinuously around the eligibility threshold, and it stays in contrast with the share of insured firms, which drops substantially around the eligibility threshold.

\section{Results}

We test the presence of moral hazard in the behavior of insured firms using standard probit and instrumental variable probit models. The results are presented in table 1 . Column 1 presents results from different specifications estimated using the full sample from 1999 - 2002. Coefficients in table 1 are recalculated to marginal effects and standard errors are estimated using the delta method. Full results are provided in the annex of this paper.

Each specification ( $a, b$ and $c$ ) contains a different set of controls as it is specified in the table. It turns out that after controlling for all observable characteristics, the incidence of sickness absence is still substantially higher in insured firms, by 3 percentage points. We further focus only on firms that are around a certain bandwidth around the eligibility threshold. Here, we present only results from a 1 million DKK bandwidth. All coefficients are consistent with the moral hazard hypothesis.

Our first estimates presented in row column (1) in table 1 are from an estimation on a full sample, whereas the results in column 2 use only data around the eligibility margin. Column 3 and 4 are taking into consideration the potential endogeneity using IV estimation.

Our IV estimates are similar to the estimates shown in columns 1 and 2 . The IV estimates in column 4 are substantially higher than in column 3 . The only difference in the specification is the adding of the difference between the wage bill and the eligibility threshold $(f(W-c))$ as a control into the specification. According to Lee and Lemieux (2009), this control should capture a potential underlying relationship between the total wage bill in a firm and the propensity to be absent due to sickness. The increase in the estimated coefficient and the time standard errors suggest that our 
instrument in combination with this control introduce noise into the estimations. However, it is also possible that our instrument is not properly excluded from the second stage regression. Nevertheless our most conservative estimate is that being employed in an insured firm increases the probability to be sick by 2.8 percentage points.

Table 1: The effect of insurance on incidence of long-term sickness (+14 days), 19992002

\begin{tabular}{|c|c|c|c|c|c|}
\hline & Controls & $\begin{array}{l}\text { (1)-full } \\
\text { sample }\end{array}$ & $\begin{array}{l}(2) \\
\text { marginal }\end{array}$ & $\begin{array}{l}\text { (3)-IV } \\
\text { marginal }\end{array}$ & $\begin{array}{l}\text { (4)-IV } \\
\text { marginal }\end{array}$ \\
\hline a) & Trend & $\begin{array}{l}0.034^{* * *} \\
(0.000)\end{array}$ & $\begin{array}{l}0.036^{* * *} \\
(0.001)\end{array}$ & $\begin{array}{l}0.057^{* * *} \\
(0.005)\end{array}$ & $\begin{array}{l}0.32^{* * *} \\
(0.033)\end{array}$ \\
\hline b) & $\begin{array}{l}\text { Age, education, gender, wage, } \\
\text { occupation, spouse }\end{array}$ & $\begin{array}{l}0.036 * * * \\
(0.000)\end{array}$ & $\begin{array}{l}0.031^{* * *} \\
(0.001)\end{array}$ & $\begin{array}{l}0.028 * * * \\
(0.008)\end{array}$ & $\begin{array}{l}0.19 * * \\
(0.073)\end{array}$ \\
\hline c) & b) + Firm size, industry, regions & $\begin{array}{l}0.047^{* * *} \\
(0.000)\end{array}$ & $\begin{array}{l}0.029 * * * \\
(0.001)\end{array}$ & $\begin{array}{l}0.028 * * * \\
(0.005)\end{array}$ & $\begin{array}{l}0.21 * * * \\
(0.082)\end{array}$ \\
\hline & $\mathrm{N}$ & 6148701 & 274939 & 274939 & 274939 \\
\hline
\end{tabular}

Note: All specifications were estimated using probit-model; the coefficients are recalculated on marginal effects

(1) Full sample

(2) Sample based on bandwidth 1million DKK around normalized eligibility threshold.

(3) IV estimates, using eligibility as a instrument for insurance, on sample with bandwidth 1 mil DKK around normalized eligibility threshold, st. errors computed using delta method

(4) IV estimates, using eligibility as a instrument for insurance, on sample with bandwidth 1 million DKK around normalized eligibility threshold, st. errors computed using delta method, controlling for $f(w-c)$

In our empirical analysis we also find that on average, the long-term sickness spells in insured firms is much shorter than in uninsured firms. Fig. 4 shows survival estimates for sickness spells in insured and uninsured firms. It is clear that sick workers in insured firms return to their work much faster than their uninsured counterparts. Table 2 is summarizing the results from a Cox proportional hazard model which is estimating the contribution of each characteristic described in annex in table 3 to the hazard of exiting sickness into work. We present only the contribution of being employed in an insured firm to this hazard. 
Table 2: The effect of insurance on the hazard of exiting sickness

\begin{tabular}{llll} 
& (+14 days) & \\
\hline & Controls & $\begin{array}{l}\text { ( } 1) \text { full } \\
\text { sample }\end{array}$ & $(2)$ marginal \\
\hline a) & No controls & $\begin{array}{l}0.241^{* * *} \\
(0.003)\end{array}$ & $0.273^{* * *}$ \\
& & $0.015)$ \\
b) & Age, education, & $0.212^{* * *}$ & $0.239^{* * *}$ \\
& gender, wage, & $(0.004)$ & $(0.015)$ \\
& occupation & & \\
c) & b) + Firm size, & $0.259^{* * *}$ & $0.229^{* * *}$ \\
& industry, wagesum & $(0.005)$ & $(0.017)$ \\
d) & c) + Regions & $0.258^{* * *}$ & $0.229^{* * *}$ \\
& & $(0.005)$ & $(0.017)$ \\
\hline & $\mathrm{N}$ & 493558 & 20429
\end{tabular}

Note: Both specifications are estimated using a Cox proportional hazard model

Our results suggest that long-term sickness in insured firms has a much less serious nature, which contradicts the adverse selection hypothesis and suggests that the higher incentives of uninsured firms to monitor their sick employees might be very important for the subsequent absence reaching into the $15+$ period. Our results are in line with the fact that the composition of sick workers on the 15th day of sickness is different between insured and uninsured firms. In particular, workers in insured firms are much less seriously sick due to the lack of monitoring during first two weeks of sickness.

The interpretation of our results leads to the following findings. While workers in insured firms have a higher sickness incidence, they have, on the other hand, a higher conditional probability to return to work, which correspond to a higher hazard ratio and shorter sickness spell. In particular, the total amount of sick workers would drop by 2.8 percentage points, which corresponds to about 5200 workers who are sick more than 2 weeks. However, our duration analysis also shows that these workers are sick about $22 \%$ longer while being employed in uninsured firms. This corresponds to 
about 24 days more per sick worker. Our calculation shows that by moving workers from insured to uninsured firms, the Danish economy would save about 250000 sickness days per year (i.e.1136 man years), which corresponds to about 12 percent of the total long-term sickness in insured firms. This can be considered as a minimum saving, given that we observe only spells at least 2 weeks long, and one can expect that the main differences are in the short-term sickness.

\section{Conclusion}

In our analysis, we show a strong and robust presence of moral hazard in firms that are participating in the insurance scheme subsidizing the expenditures related to absence due to sickness of employees. We use a fuzzy regression discontinuity design that is justified by an eligibility threshold exogenously set by the public authority.

Our results have the following implications. First, while designing the insurance scheme, policymakers need to take into account that the majority of players behave rationally and exploit the insurance scheme, which could result in high public expenditures. Second, we show that mainly firms that tend to have a higher risk of sickness absence for lower-skilled workers choose the insurance scheme. Third, insured firms have lower incentives to control their workers while being off sick. This moral hazard increases the sickness absence even further and means that the design of the insurance scheme has adverse effects on economic efficiency. Our estimates show that the design of the current insurance scheme costs at least about 1100 full time jobs per year, without counting the loss due to more short time sickness ( $<2$ weeks). 


\section{References}

Battistin, Erich and Rottere, Enrico (2008): Ineligibles and eligible non-participants as a double comparison group in regression-discontinuity designs, Journal of Econometrics 142, 715-730

Boheim, René and Leoni, Thomas (2011): Firms' Moral Hazard and Sickness Absences, IZA DP 6005.

Brown S., and Sessions J. G. (1996): The Economics of Absence: Theory and Evidence, Journal of Economic Surveys Vol. 10, No. 1.

Lee, David S. and Lemieux, Thomas (2009): Regression Discontinuity Design in Economics, NBER Working Paper 14728.

Ziebarth, Nicolas R. (2009): Long-term absenteeism and Moral Hazard - Evidence From a Natural Experiment, Discussion paper 888, DIW Berlin.

Johansson, P. and M. Palme (2005): Moral hazard and sickness insurance. Journal of Public Economics 89, 1879-1890.

Ose, S. O. (2005): Working conditions, compensation and absenteeism. Journal of Health Economics $24,161-188$.

Markussen, S., Roed K., Rogeberg O. J., Gaure S. (2011): The Anatomy of Absenteeism, Journal of Health Economics 30 (2011) 277-292 


\section{Annex:}

\section{Cost-Benefit Analysis of Sickness Insurance}

The insurance scheme is designed in such a way that firms have to pay a premium to be in the system. This, of course, means that participation is not profitable for all firms. A simple cost-benefit firm-level analysis of sickness insurance proves this. The employer is indifferent about entering an insurance scheme if the cost of sickness is the same with and without insurance. From institutional reasons and for the sake of simplicity, we consider two situations. Firms either employ low-wage workers or high-wage workers. Low-wage workers are defined as earning below 1.1 times the maximum unemployment benefit (which is equal to the sickness benefit), and high-wage workers earn above. The equations 1 and 2 represent equality between costs under insurance (left hand side) and costs of sickness without insurance (right hand side).

1) $0,0069 * W+s^{*} W * 0,1=s * W$ if $W<1.1 U$

2) $0,0069 * W+s *(W-U)=s * W \quad$ if $W>1.1 U$

Where $W$ is the yearly wage bill in a firm, $U$ is the yearly sum of all potential unemployment benefits for a given number of employees, and $s$ is the share of lost working hours due to sickness in a given firm in a given year.

We also find the indifference point for a certain level of the total wage bill. If the annual average wage is lower than 1.1 times the unemployment benefits, the threshold does not depend on wages in the firm. For this level of wage bill, one can find the exact level of total sickness when the firm is indifferent about being insured or not as

1) $s=0,0076$

It means that it is profitable to insure if total sickness is more than $0,76 \%$ of the total number of working hours. This means that at least $50 \%$ of workers should be absent at least 4 days per year to make the insurance scheme profitable.

The second case involves high-wage firms. In this case, the indifference point depends on the total wage bill.

2) $s=0,0069 *(W / U)$

The intuition is that the higher the wages the more workers have to be sick in order to cover the cost of insurance. 
Fig. 1: Distribution of firms around the eligibility threshold

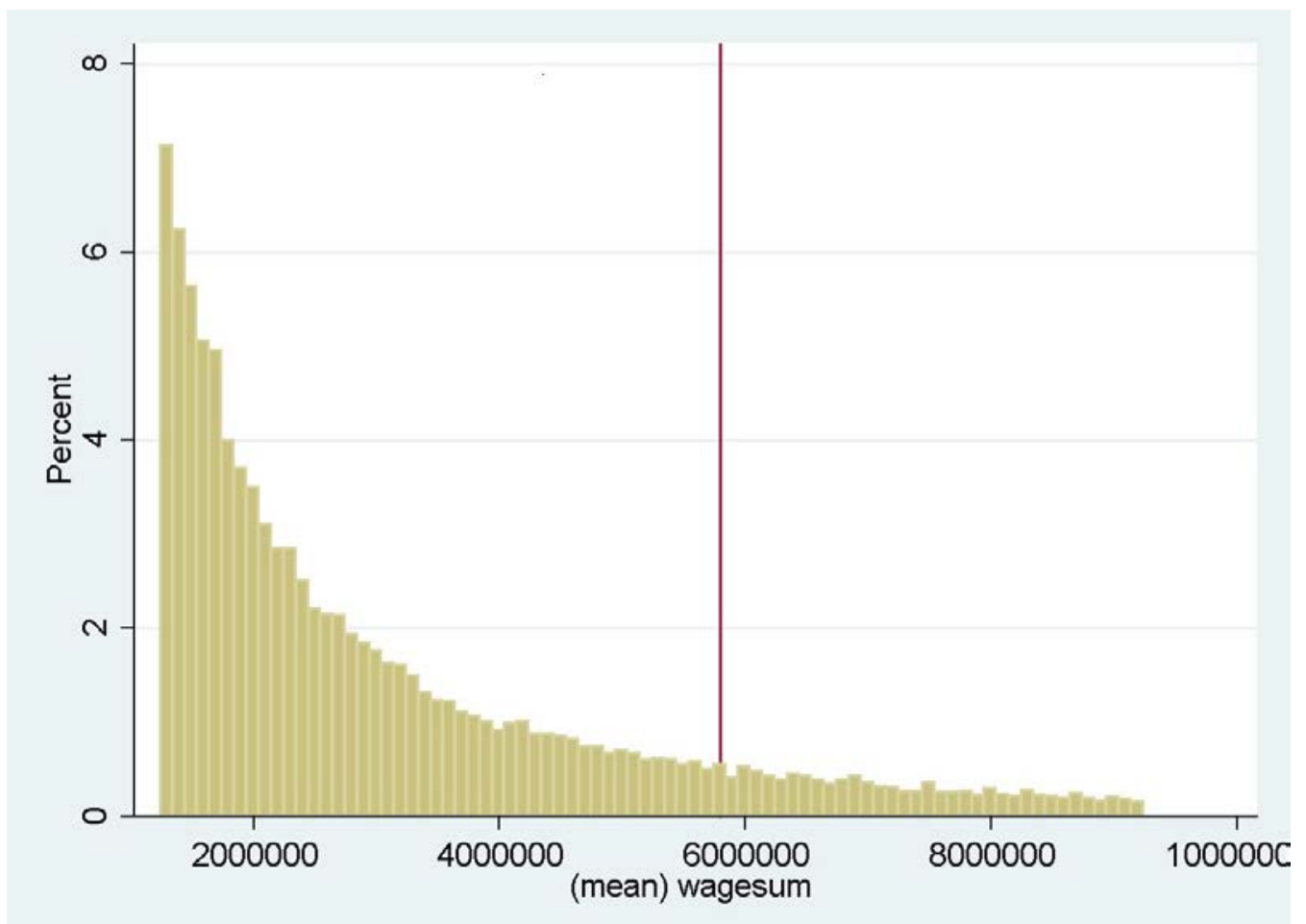

Fig. 2: Share of insured firms, females, and workers with children by wage groups

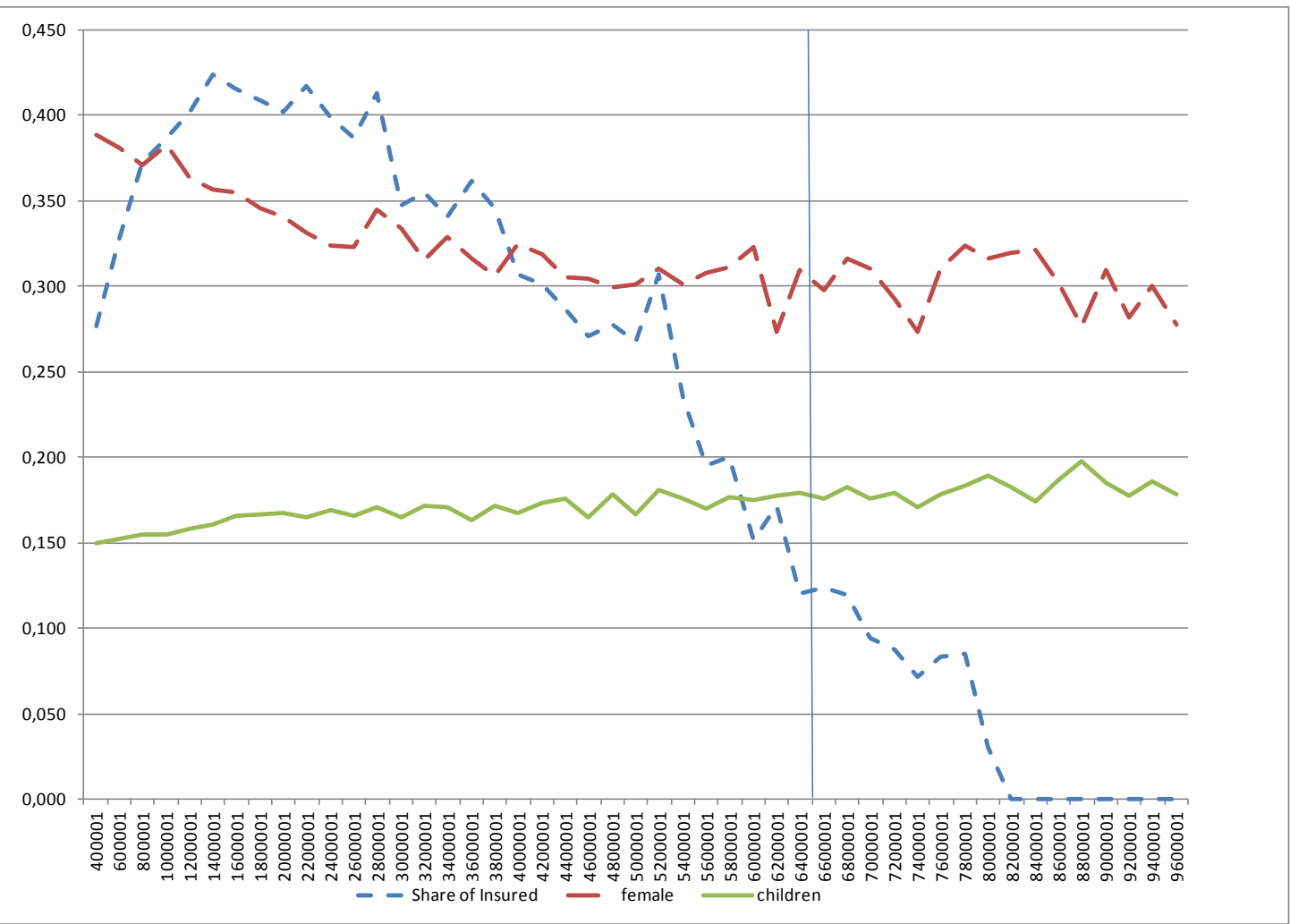


Fig. 3: Incidence of sickness absence vs. share of insured firms in the sample

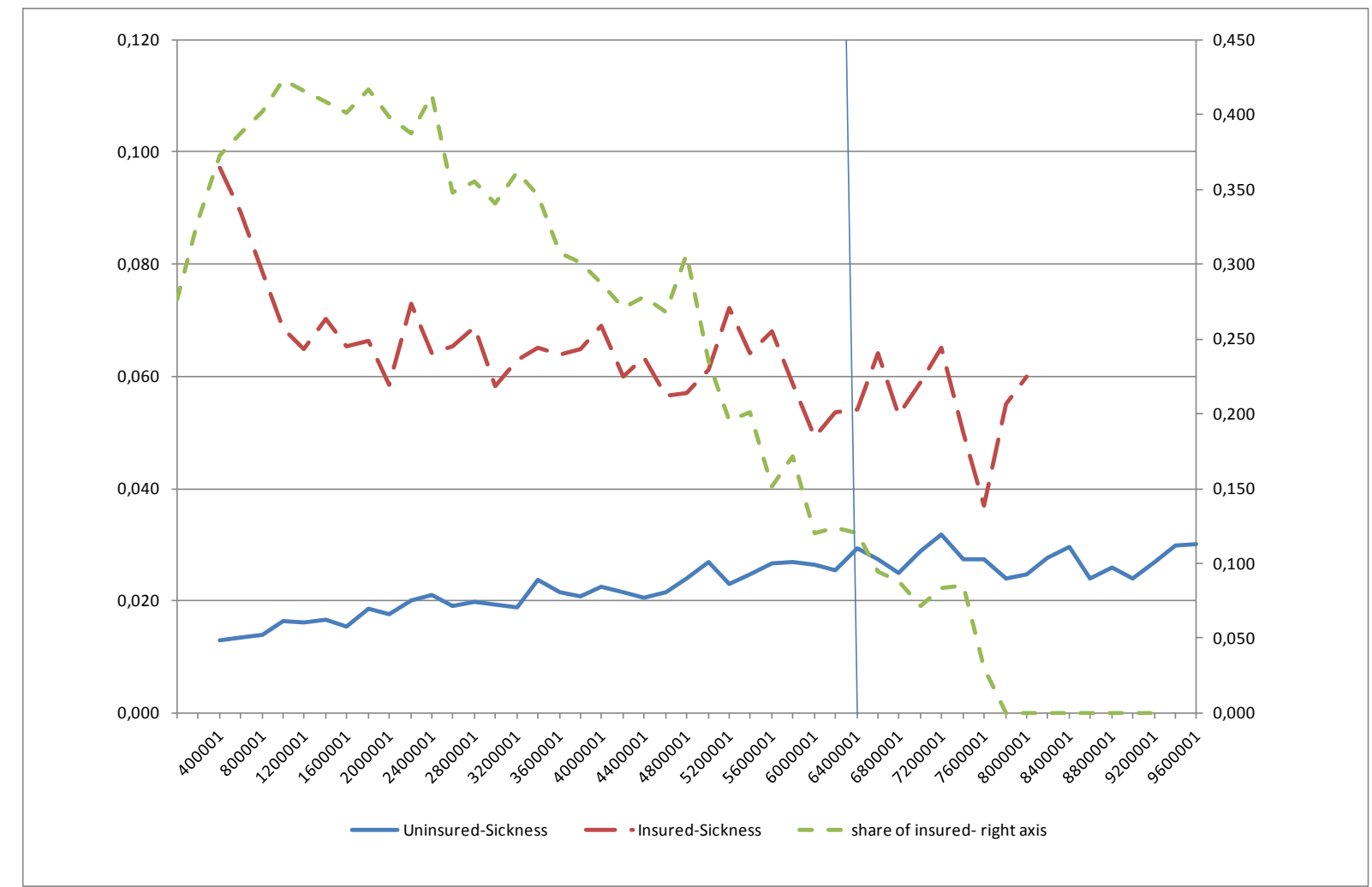

Note: Sickness incidence is on the left axis, share of insured firms on the right axis. 
Table 3: Descriptive statistics, 1999-2002, outcome variables are in bold

\begin{tabular}{|c|c|c|c|c|c|c|}
\hline & \multicolumn{2}{|c|}{$\begin{array}{l}\text { Insured - eligible } \\
\text { mean (sd) }\end{array}$} & \multicolumn{2}{|c|}{$\begin{array}{l}\text { Uninsured - eligible } \\
\text { mean (sd) }\end{array}$} & \multicolumn{2}{|c|}{ Non-eligible } \\
\hline Sickness (>14 days) & 0.10 & $(0.30)$ & 0.03 & $(0.18)$ & 0.06 & $(0.24)$ \\
\hline Duration (>14 days) & 113.63 & (159.91) & 167.72 & $(170.43)$ & 136.78 & (157.74) \\
\hline Age & 36.24 & $(14.49)$ & 37.48 & $(15.55)$ & 38.65 & $(13.27)$ \\
\hline Wage & 158295 & $(120115)$ & 148242 & (150597) & 237973 & $(180323)$ \\
\hline Children - age 1 & 0.04 & $(0.27)$ & 0.04 & $(0.27)$ & 0.05 & $(0.26)$ \\
\hline Children - age 3 & 0.09 & $(0.54)$ & 0.08 & $(0.56)$ & 0.09 & $(0.48)$ \\
\hline Spouse & 0.76 & $(0.43)$ & 0.75 & $(0.43)$ & 0.76 & $(0.43)$ \\
\hline Female & 0.39 & $(0.49)$ & 0.44 & $(0.50)$ & 0.38 & $(0.49)$ \\
\hline Primary school & 0.37 & $(0.48)$ & 0.33 & $(0.47)$ & 0.28 & $(0.45)$ \\
\hline Vocational school & 0.42 & (0.49) & 0.33 & $(0.47)$ & 0.37 & $(0.48)$ \\
\hline Secondary school & 0.10 & $(0.30)$ & 0.13 & $(0.34)$ & 0.14 & $(0.35)$ \\
\hline Higher education & 0.05 & $(0.21)$ & 0.11 & $(0.32)$ & 0.14 & $(0.34)$ \\
\hline Employees & 13.18 & $(10.97)$ & 11.99 & (14.91) & 3278.96 & $(6515)$ \\
\hline Wage sum & 2138902 & (1499686) & 1990155 & (1787129) & $7.96 e+8$ & $(1.47 e+09)$ \\
\hline Full-time & 0.75 & $(0.43)$ & 0.67 & $(0.47)$ & 0.83 & $(0.38)$ \\
\hline Salaried_employee & 0.71 & $(0.46)$ & 0.84 & $(0.36)$ & 0.71 & $(0.45)$ \\
\hline Not specified Earner & 0.21 & $(0.40)$ & 0.23 & $(0.42)$ & 0.07 & $(0.25)$ \\
\hline CEO & 0.02 & $(0.12)$ & 0.02 & $(0.12)$ & 0.03 & $(0.16)$ \\
\hline Top earner & 0.02 & $(0.13)$ & 0.04 & (0.19) & 0.09 & $(0.28)$ \\
\hline Intermediate earner & 0.03 & $(0.18)$ & 0.06 & $(0.24)$ & 0.14 & $(0.35)$ \\
\hline Low earner & 0.41 & $(0.49)$ & 0.26 & $(0.44)$ & 0.41 & $(0.49)$ \\
\hline Other & 0.09 & $(0.28)$ & 0.06 & $(0.24)$ & 0.08 & $(0.28)$ \\
\hline Secondary employ. & 0.18 & (0.39) & 0.27 & $(0.44)$ & 0.16 & $(0.37)$ \\
\hline Non-specified & 0.04 & $(0.20)$ & 0.06 & $(0.24)$ & 0.02 & $(0.16)$ \\
\hline Agriculture, fishery & 0.07 & $(0.25)$ & 0.08 & $(0.27)$ & 0.01 & $(0.11)$ \\
\hline Manufacturing & 0.18 & (0.39) & 0.11 & $(0.31)$ & 0.34 & $(0.48)$ \\
\hline Energy, water dist. & 0.00 & $(0.02)$ & 0.01 & $(0.08)$ & 0.01 & $(0.08)$ \\
\hline Construction & 0.23 & $(0.42)$ & 0.07 & $(0.25)$ & 0.06 & $(0.23)$ \\
\hline Retail, hotels, rest. & 0.30 & $(0.46)$ & 0.36 & $(0.48)$ & 0.21 & $(0.41)$ \\
\hline Transport, telecom. & 0.05 & $(0.22)$ & 0.06 & $(0.24)$ & 0.12 & $(0.32)$ \\
\hline Financial companies & 0.10 & $(0.30)$ & 0.19 & (0.39) & 0.19 & (0.39) \\
\hline Culture & 0.07 & $(0.26)$ & 0.13 & $(0.34)$ & 0.06 & $(0.25)$ \\
\hline Unknown industry & 0.00 & $(0.01)$ & 0.00 & $(0.03)$ & 0.00 & $(0.00)$ \\
\hline Copenhagen & 0.25 & $(0.43)$ & 0.24 & $(0.43)$ & 0.22 & $(0.42)$ \\
\hline Zealand & 0.24 & $(0.42)$ & 0.28 & $(0.45)$ & 0.33 & $(0.47)$ \\
\hline Southern Denmark & 0.12 & $(0.33)$ & 0.11 & $(0.32)$ & 0.10 & $(0.30)$ \\
\hline Central Jutland & 0.25 & $(0.43)$ & 0.22 & $(0.41)$ & 0.21 & $(0.41)$ \\
\hline Northern Jutland & 0.15 & $(0.35)$ & 0.15 & $(0.36)$ & 0.14 & $(0.35)$ \\
\hline year_1 & 0.26 & $(0.44)$ & 0.26 & $(0.44)$ & 0.24 & $(0.43)$ \\
\hline year_2 & 0.25 & $(0.44)$ & 0.24 & $(0.43)$ & 0.25 & $(0.43)$ \\
\hline year_3 & 0.25 & $(0.43)$ & 0.24 & $(0.43)$ & 0.25 & $(0.43)$ \\
\hline year_4 & 0.24 & $(0.43)$ & 0.25 & $(0.43)$ & 0.26 & $(0.44)$ \\
\hline$N$ & 745022 & & 1471620 & & 3983934 & \\
\hline
\end{tabular}


Table 4: Descriptive statistics around for firms in bandwidth 1 million DKK around eligibility threshold

\begin{tabular}{|c|c|c|c|c|c|c|}
\hline & \multicolumn{2}{|c|}{ Insured - eligible } & \multicolumn{2}{|c|}{$\begin{array}{c}\text { Uninsured - eligible } \\
\text { mean (sd) }\end{array}$} & \multicolumn{2}{|l|}{$\begin{array}{l}\text { Non- eligible } \\
\text { mean(sd) }\end{array}$} \\
\hline sickness14 & 0.09 & $(0.28)$ & 0.05 & (0.21) & 0.04 & $(0.21)$ \\
\hline Duration14 & 117.75 & (163.10) & 152.18 & (165.29) & 148.71 & (160.23) \\
\hline Age & 36.21 & $(13.46)$ & 38.34 & $(14.11)$ & 36.42 & $(14.74)$ \\
\hline Wage & 191534 & (134661) & 209823 & (169676) & 195294 & (168387) \\
\hline children_1 & 0.05 & $(0.27)$ & 0.04 & $(0.27)$ & 0.04 & $(0.25)$ \\
\hline children_3 & 0.09 & $(0.49)$ & 0.09 & $(0.53)$ & 0.09 & $(0.50)$ \\
\hline Spouse & 0.76 & $(0.43)$ & 0.76 & $(0.43)$ & 0.76 & $(0.43)$ \\
\hline Female & 0.32 & $(0.47)$ & 0.36 & $(0.48)$ & 0.35 & $(0.48)$ \\
\hline Primary & 0.35 & $(0.48)$ & 0.29 & $(0.45)$ & 0.28 & $(0.45)$ \\
\hline Vocational & 0.44 & $(0.50)$ & 0.39 & $(0.49)$ & 0.37 & $(0.48)$ \\
\hline Secondary & 0.10 & $(0.30)$ & 0.13 & $(0.34)$ & 0.12 & (0.33) \\
\hline Higher & 0.05 & $(0.22)$ & 0.12 & $(0.32)$ & 0.10 & $(0.30)$ \\
\hline Employees & 31.39 & (13.68) & 28.59 & (20.89) & 35.11 & (23.17) \\
\hline Wage sum & 5685345 & (289269) & 5730567 & (294272) & 6722619 & (283129) \\
\hline Full-time & 0.81 & $(0.40)$ & 0.79 & $(0.40)$ & 0.74 & $(0.44)$ \\
\hline Salaried_employee & 0.63 & $(0.48)$ & 0.75 & $(0.43)$ & 0.76 & $(0.43)$ \\
\hline Not specified Earner & 0.11 & $(0.32)$ & 0.11 & $(0.31)$ & 0.12 & $(0.32)$ \\
\hline CEO & 0.03 & $(0.18)$ & 0.04 & $(0.19)$ & 0.03 & $(0.18)$ \\
\hline Top earner & 0.02 & $(0.13)$ & 0.06 & $(0.23)$ & 0.05 & $(0.21)$ \\
\hline Intermediate earner & 0.06 & $(0.23)$ & 0.11 & $(0.32)$ & 0.10 & $(0.30)$ \\
\hline Low earner & 0.49 & $(0.50)$ & 0.38 & $(0.49)$ & 0.37 & $(0.48)$ \\
\hline Other & 0.11 & $(0.32)$ & 0.09 & $(0.28)$ & 0.09 & $(0.28)$ \\
\hline Secondary employ. & 0.15 & $(0.35)$ & 0.18 & $(0.38)$ & 0.22 & $(0.41)$ \\
\hline Non-specified & 0.03 & $(0.17)$ & 0.04 & $(0.19)$ & 0.03 & $(0.18)$ \\
\hline Agriculture, fishery & 0.05 & $(0.21)$ & 0.02 & $(0.15)$ & 0.03 & $(0.17)$ \\
\hline Manufacturing & 0.30 & $(0.46)$ & 0.19 & $(0.40)$ & 0.21 & $(0.41)$ \\
\hline Energy, water dist. & 0.00 & $(0.00)$ & 0.00 & $(0.06)$ & 0.00 & $(0.05)$ \\
\hline Construction & 0.23 & $(0.42)$ & 0.11 & $(0.31)$ & 0.10 & $(0.30)$ \\
\hline Retail, hotels, rest. & 0.24 & $(0.43)$ & 0.31 & $(0.46)$ & 0.30 & $(0.46)$ \\
\hline Transport, telecom. & 0.05 & $(0.22)$ & 0.08 & $(0.28)$ & 0.12 & $(0.32)$ \\
\hline Financial companies & 0.11 & $(0.31)$ & 0.17 & $(0.38)$ & 0.18 & $(0.38)$ \\
\hline Culture & 0.02 & $(0.15)$ & 0.10 & $(0.30)$ & 0.07 & $(0.25)$ \\
\hline Unknown industry & 0.00 & $(0.00)$ & 0.00 & $(0.00)$ & 0.00 & $(0.00)$ \\
\hline Copenhagen & 0.24 & $(0.43)$ & 0.24 & $(0.43)$ & 0.24 & $(0.42)$ \\
\hline Zealand & 0.25 & $(0.43)$ & 0.30 & $(0.46)$ & 0.29 & $(0.45)$ \\
\hline Southern Denmark & 0.13 & $(0.33)$ & 0.10 & $(0.30)$ & 0.10 & $(0.30)$ \\
\hline Central Jutland & 0.25 & $(0.43)$ & 0.21 & $(0.41)$ & 0.22 & $(0.41)$ \\
\hline Northern Jutland & 0.14 & $(0.34)$ & 0.15 & $(0.36)$ & 0.15 & $(0.36)$ \\
\hline year_1 & 0.25 & $(0.43)$ & 0.26 & $(0.44)$ & 0.23 & $(0.42)$ \\
\hline year_2 & 0.27 & $(0.44)$ & 0.24 & $(0.42)$ & 0.24 & $(0.43)$ \\
\hline year_3 & 0.25 & $(0.43)$ & 0.24 & $(0.43)$ & 0.25 & $(0.43)$ \\
\hline year_4 & 0.24 & $(0.42)$ & 0.27 & $(0.44)$ & 0.28 & $(0.45)$ \\
\hline$N$ & 34413 & & 110526 & & 117078 & \\
\hline
\end{tabular}


Fig. 4: Survival estimates of sickness spells in insured vs. uninsured firms (15-100 days)

Kaplan-Meier survival estimates

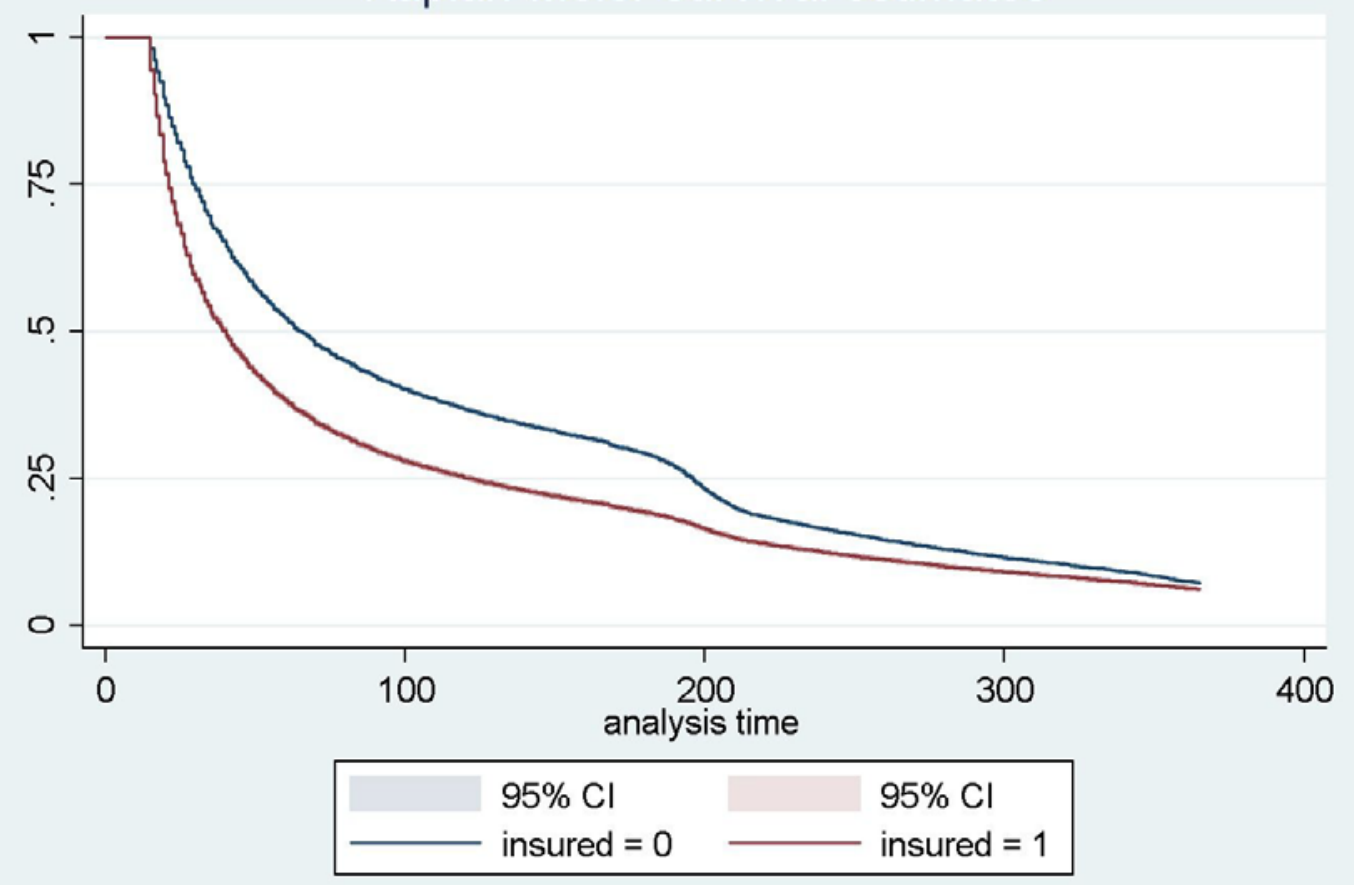


Table 5: Effects of characteristics on propensity to be sick more than 2 weeks, coefficients estimated using a probit model, full specification, including first stage

(1) (2) (3) (4)

\begin{tabular}{|c|c|c|c|c|}
\hline Insured & $\begin{array}{c}0.426 \\
(0.003)\end{array}$ & $\begin{array}{c}0.297^{* * *} \\
(0.011)\end{array}$ & $\begin{array}{c}0.278^{* * *} \\
(0.075)\end{array}$ & $\begin{array}{l}1.392^{* * *} \\
(0.370)\end{array}$ \\
\hline Eligible & $\begin{array}{c}-0.166^{* * *} \\
(0.003)\end{array}$ & $\begin{array}{l}-0.002 \\
(0.009)\end{array}$ & & \\
\hline Age & $\begin{array}{l}0.004^{* * *} \\
(0.000)\end{array}$ & $\begin{array}{l}0.005^{* * *} \\
(0.000)\end{array}$ & $\begin{array}{l}0.005^{* * *} \\
(0.000)\end{array}$ & $\begin{array}{l}0.004^{* * *} \\
(0.000)\end{array}$ \\
\hline Wage & $\begin{array}{c}-0.000^{* * * *} \\
(0.000)\end{array}$ & $\begin{array}{c}-0.000^{* * *} \\
(0.000)\end{array}$ & $\begin{array}{c}-0.000^{* * *} \\
(0.000)\end{array}$ & $\begin{array}{c}-0.000^{* * * *} \\
(0.000)\end{array}$ \\
\hline children_1 & $\begin{array}{l}0.979^{* * *} \\
(0.004)\end{array}$ & $\begin{array}{l}0.912^{* * *} \\
(0.017)\end{array}$ & $\begin{array}{c}0.912^{* * * *} \\
(0.017)\end{array}$ & $\begin{array}{c}0.824^{* * * *} \\
(0.063)\end{array}$ \\
\hline children_3 & $\begin{array}{l}-0.331^{* * *} \\
(0.004)\end{array}$ & $\begin{array}{c}-0.315^{* * *} \\
(0.016)\end{array}$ & $\begin{array}{c}-0.315^{* * *} \\
(0.016)\end{array}$ & $\begin{array}{c}-0.289^{* * *} \\
(0.025)\end{array}$ \\
\hline Primary & $\begin{array}{l}0.171^{* * *} \\
(0.003)\end{array}$ & $\begin{array}{l}0.179^{* * *} \\
(0.015)\end{array}$ & $\begin{array}{c}0.179^{* * *} \\
(0.015)\end{array}$ & $\begin{array}{c}0.118^{* * *} \\
(0.030)\end{array}$ \\
\hline Vocational & $\begin{array}{l}0.155^{* * *} \\
(0.003)\end{array}$ & $\begin{array}{l}0.168^{* * *} \\
(0.015)\end{array}$ & $\begin{array}{l}0.168^{* * *} \\
(0.015)\end{array}$ & $\begin{array}{l}0.114^{* * *} \\
(0.028)\end{array}$ \\
\hline Higher & $\begin{array}{l}0.074^{* * *} \\
(0.004)\end{array}$ & $\begin{array}{l}0.090^{* * *} \\
(0.021)\end{array}$ & $\begin{array}{c}0.091^{* * *} \\
(0.022)\end{array}$ & $\begin{array}{c}0.041 \\
(0.028)\end{array}$ \\
\hline Employees & $\begin{array}{c}-0.000^{* * * *} \\
(0.000)\end{array}$ & $\begin{array}{c}-0.001^{* * * *} \\
(0.000)\end{array}$ & $\begin{array}{c}-0.001^{* * * *} \\
(0.000)\end{array}$ & $\begin{array}{c}-0.002^{* * * *} \\
(0.000)\end{array}$ \\
\hline Wage sum & $\begin{array}{l}0.000^{* * * *} \\
(0.000)\end{array}$ & & & \\
\hline Full-time & $\begin{array}{c}0.457^{* * *} \\
(0.004)\end{array}$ & $\begin{array}{c}0.502^{* * *} \\
(0.018)\end{array}$ & $\begin{array}{c}0.502^{* * *} \\
(0.018)\end{array}$ & $\begin{array}{l}0.428^{* * *} \\
(0.046)\end{array}$ \\
\hline $\begin{array}{l}\text { Salaried_empl } \\
\text { oyee }\end{array}$ & $-0.236^{* * *}$ & $-0.192^{* * *}$ & $-0.192^{* * *}$ & $-0.149^{* * *}$ \\
\hline & $(0.002)$ & $(0.011)$ & $(0.011)$ & $(0.024)$ \\
\hline Spouse & $\begin{array}{l}-0.005^{*} \\
(0.002)\end{array}$ & $\begin{array}{l}-0.018 \\
(0.011)\end{array}$ & $\begin{array}{l}-0.018 \\
(0.011)\end{array}$ & $\begin{array}{l}-0.002 \\
(0.012)\end{array}$ \\
\hline Female & $\begin{array}{l}0.376^{* * *} \\
(0.002)\end{array}$ & $\begin{array}{c}0.367^{* * *} \\
(0.011)\end{array}$ & $\begin{array}{c}0.367^{* * *} \\
(0.011)\end{array}$ & $\begin{array}{c}0.332^{* * *} \\
(0.027)\end{array}$ \\
\hline industry_2 & $\begin{array}{c}0.069^{* * *} \\
(0.006)\end{array}$ & $\begin{array}{l}0.063^{*} \\
(0.028)\end{array}$ & $\begin{array}{l}0.064^{*} \\
(0.029)\end{array}$ & $\begin{array}{l}-0.004 \\
(0.036)\end{array}$ \\
\hline industry_3 & $\begin{array}{l}-0.025 \\
(0.015)\end{array}$ & $\begin{array}{l}-0.056 \\
(0.101)\end{array}$ & $\begin{array}{l}-0.056 \\
(0.101)\end{array}$ & $\begin{array}{l}-0.025 \\
(0.093)\end{array}$ \\
\hline industry_4 & $\begin{array}{l}0.060^{* * *} \\
(0.007)\end{array}$ & $\begin{array}{l}0.093^{* *} \\
(0.030)\end{array}$ & $\begin{array}{l}0.095^{* * *} \\
(0.031)\end{array}$ & $\begin{array}{l}-0.037 \\
(0.055)\end{array}$ \\
\hline industry_5 & $\begin{array}{c}-0.021^{* * * *} \\
(0.006)\end{array}$ & $\begin{array}{c}0.024 \\
(0.028)\end{array}$ & $\begin{array}{c}0.023 \\
(0.029)\end{array}$ & $\begin{array}{l}0.096^{* *} \\
(0.036)\end{array}$ \\
\hline industry_6 & $\begin{array}{l}0.107^{* * *} \\
(0.007)\end{array}$ & $\begin{array}{l}0.065^{*} \\
(0.031)\end{array}$ & $\begin{array}{l}0.063^{*} \\
(0.032)\end{array}$ & $\begin{array}{l}0.160^{* * *} \\
(0.043)\end{array}$ \\
\hline industry_7 & $\begin{array}{l}-0.009 \\
(0.007)\end{array}$ & $\begin{array}{c}0.007 \\
(0.030)\end{array}$ & $\begin{array}{c}0.005 \\
(0.031)\end{array}$ & $\begin{array}{l}0.090^{*} \\
(0.041)\end{array}$ \\
\hline industry_8 & $0.031^{* * *}$ & 0.054 & 0.052 & $0.158^{* * *}$ \\
\hline
\end{tabular}




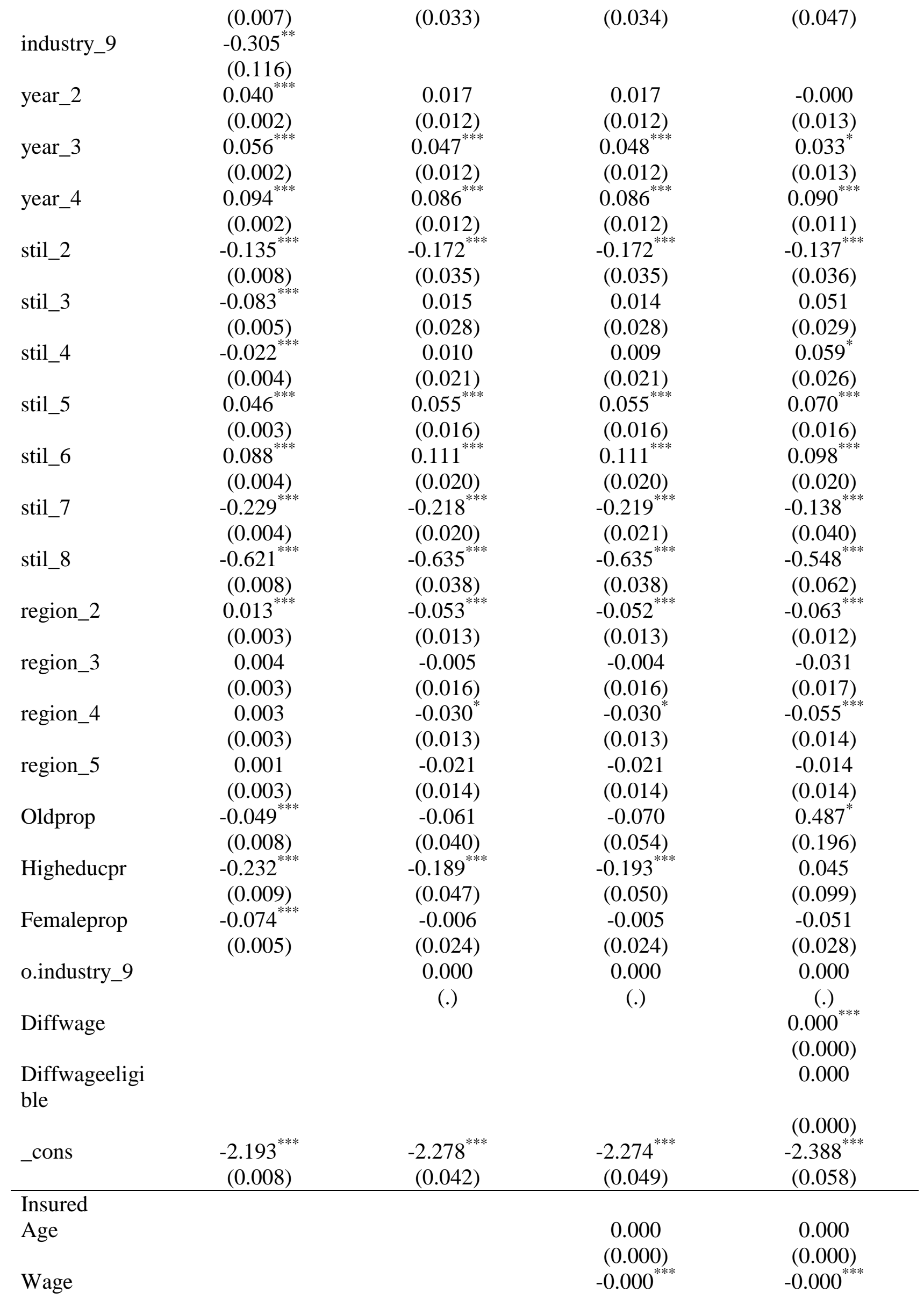




\begin{tabular}{|c|c|c|}
\hline & $(0.000)$ & $(0.000)$ \\
\hline \multirow[t]{2}{*}{ children_1 } & 0.006 & $0.006^{*}$ \\
\hline & $(0.003)$ & $(0.003)$ \\
\hline \multirow[t]{2}{*}{ children_3 } & 0.002 & 0.002 \\
\hline & $(0.002)$ & $(0.002)$ \\
\hline \multirow[t]{2}{*}{ Primary } & $0.039^{* * *}$ & $0.040^{* * * *}$ \\
\hline & $(0.003)$ & $(0.003)$ \\
\hline \multirow[t]{2}{*}{ Vocational } & $0.034^{* * *}$ & $0.034^{* * *}$ \\
\hline & $(0.003)$ & $(0.003)$ \\
\hline \multirow[t]{2}{*}{ Higher } & $0.037^{* * *}$ & $0.037^{* * *}$ \\
\hline & $(0.003)$ & $(0.003)$ \\
\hline \multirow[t]{2}{*}{ Employees } & $0.000^{* * *}$ & $0.001^{* * *}$ \\
\hline & $(0.000)$ & $(0.000)$ \\
\hline \multirow[t]{2}{*}{ Full-time } & $0.024^{* * *}$ & $0.025^{* * *}$ \\
\hline & $(0.003)$ & $(0.003)$ \\
\hline \multirow{2}{*}{$\begin{array}{l}\text { Salaried_empl } \\
\text { oyee }\end{array}$} & $-0.023^{* * *}$ & $-0.023^{* * *}$ \\
\hline & $(0.003)$ & $(0.003)$ \\
\hline \multirow{2}{*}{ Spouse } & $-0.012^{* * *}$ & $-0.012^{* * *}$ \\
\hline & $(0.002)$ & $(0.002)$ \\
\hline \multirow[t]{2}{*}{ Female } & 0.002 & 0.002 \\
\hline & $(0.002)$ & $(0.002)$ \\
\hline \multirow[t]{2}{*}{ industry_2 } & $0.051^{* * *}$ & $0.054^{* * *}$ \\
\hline & $(0.007)$ & $(0.007)$ \\
\hline \multirow[t]{2}{*}{ industry_3 } & $-0.024^{* *}$ & $-0.021^{* *}$ \\
\hline & $(0.007)$ & $(0.008)$ \\
\hline \multirow[t]{2}{*}{ industry_4 } & $0.106^{* * *}$ & $0.107^{* * *}$ \\
\hline & $(0.007)$ & $(0.007)$ \\
\hline \multirow[t]{2}{*}{ industry_5 } & $-0.069^{* * *}$ & $-0.067^{* * *}$ \\
\hline & $(0.006)$ & $(0.006)$ \\
\hline \multirow[t]{2}{*}{ industry_6 } & $-0.088^{* * *}$ & $-0.090^{* * *}$ \\
\hline & $(0.007)$ & $(0.007)$ \\
\hline \multirow[t]{2}{*}{ industry_7 } & $-0.077^{* * *}$ & $-0.076^{* * *}$ \\
\hline & $(0.006)$ & $(0.006)$ \\
\hline \multirow[t]{2}{*}{ industry_8 } & $-0.095^{* * *}$ & $-0.098^{* * *}$ \\
\hline & $(0.007)$ & $(0.007)$ \\
\hline \multirow[t]{2}{*}{ o.industry_9 } & 0.000 & 0.000 \\
\hline & (.) & (.) \\
\hline \multirow[t]{2}{*}{ year_2 } & $0.014^{* * *}$ & $0.014^{* * *}$ \\
\hline & $(0.002)$ & $(0.002)$ \\
\hline \multirow[t]{2}{*}{ year_3 } & $0.008^{* * *}$ & $0.009^{* * *}$ \\
\hline & $(0.002)$ & $(0.002)$ \\
\hline \multirow[t]{2}{*}{ year_4 } & $-0.011^{* * *}$ & $-0.010^{* * * *}$ \\
\hline & $(0.002)$ & $(0.002)$ \\
\hline \multirow[t]{2}{*}{ stil_2 } & $-0.016^{* *}$ & $-0.016^{* *}$ \\
\hline & $(0.006)$ & $(0.006)$ \\
\hline \multirow[t]{2}{*}{ stil_3 } & $-0.034^{* * *}$ & $-0.033^{* * *}$ \\
\hline & $(0.004)$ & $(0.004)$ \\
\hline stil_4 & $-0.046^{* * *}$ & $-0.045^{* * *}$ \\
\hline & $(0.004)$ & $(0.004)$ \\
\hline
\end{tabular}




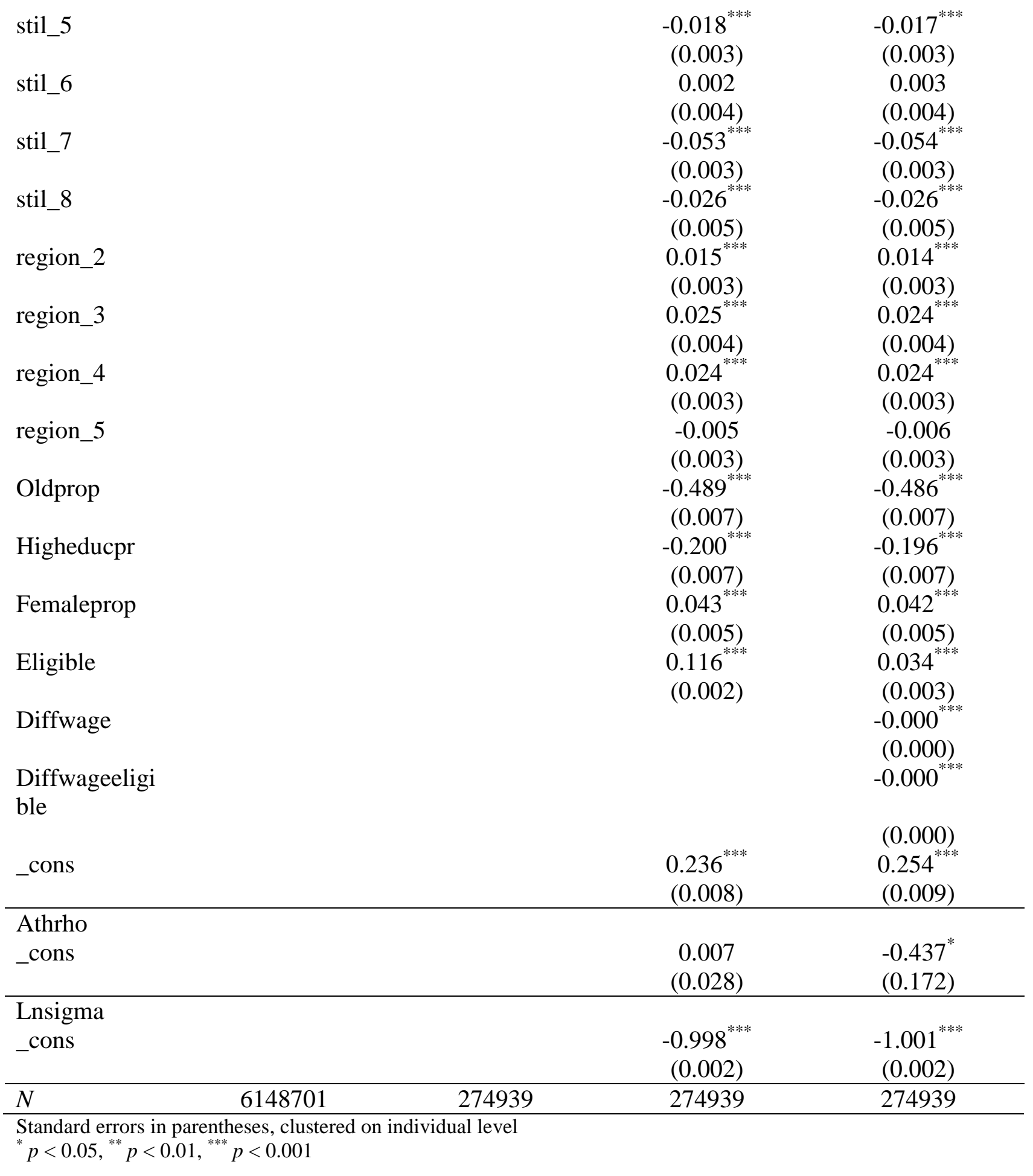


Table 6: Effects of characteristics on propensity to be sick more than 2 weeks, coefficients estimated using probit model, only individual specific characteristics

\begin{tabular}{|c|c|c|c|c|}
\hline & $\begin{array}{c}\text { (1) } \\
\text { Full sample }\end{array}$ & $\begin{array}{c}\text { (2) } \\
\text { Marginal firms }\end{array}$ & $\begin{array}{c}\text { (3) } \\
\text { Marginal- IV }\end{array}$ & $\begin{array}{c}(4) \\
\text { Marginal - IV }\end{array}$ \\
\hline Insured & $\begin{array}{l}0.331^{* * *} \\
(0.002)\end{array}$ & $\begin{array}{l}0.312^{* * *} \\
(0.010)\end{array}$ & $\begin{array}{c}0.280^{* * *} \\
(0.075)\end{array}$ & $\begin{array}{l}1.448^{* * *} \\
(0.373)\end{array}$ \\
\hline Age & $\begin{array}{l}0.004^{* * *} \\
(0.000)\end{array}$ & $\begin{array}{l}0.004^{* * * *} \\
(0.000)\end{array}$ & $\begin{array}{l}0.004^{* * *} \\
(0.000)\end{array}$ & $\begin{array}{l}0.006^{* * *} \\
(0.000)\end{array}$ \\
\hline Wage & $\begin{array}{c}-0.000^{* * *} \\
(0.000)\end{array}$ & $\begin{array}{c}-0.000^{* * *} \\
(0.000)\end{array}$ & $\begin{array}{c}-0.000^{* * *} \\
(0.000)\end{array}$ & $\begin{array}{c}-0.000^{* * *} \\
(0.000)\end{array}$ \\
\hline children_1 & $\begin{array}{l}0.975^{* * *} \\
(0.003)\end{array}$ & $\begin{array}{l}0.908^{* * *} \\
(0.013)\end{array}$ & $\begin{array}{c}0.908^{* * *} \\
(0.013)\end{array}$ & $\begin{array}{c}0.809^{* * * *} \\
(0.070)\end{array}$ \\
\hline children_3 & $\begin{array}{c}-0.329^{* * *} \\
(0.002)\end{array}$ & $\begin{array}{c}-0.315^{* * *} \\
(0.009)\end{array}$ & $\begin{array}{c}-0.315^{* * *} \\
(0.009)\end{array}$ & $\begin{array}{c}-0.285^{* * *} \\
(0.024)\end{array}$ \\
\hline Primary & $\begin{array}{c}0.174^{* * * *} \\
(0.003)\end{array}$ & $\begin{array}{l}0.188^{* * *} \\
(0.014)\end{array}$ & $\begin{array}{l}0.189^{* * *} \\
(0.015)\end{array}$ & $\begin{array}{l}0.112^{* *} \\
(0.036)\end{array}$ \\
\hline Vocational & $\begin{array}{l}0.145^{* * *} \\
(0.003)\end{array}$ & $\begin{array}{l}0.174^{* * *} \\
(0.014)\end{array}$ & $\begin{array}{l}0.175^{* * *} \\
(0.014)\end{array}$ & $\begin{array}{l}0.105^{* *} \\
(0.033)\end{array}$ \\
\hline Higher & $\begin{array}{l}0.025^{* * *} \\
(0.004)\end{array}$ & $\begin{array}{l}0.061^{* * *} \\
(0.021)\end{array}$ & $\begin{array}{l}0.061^{* *} \\
(0.021)\end{array}$ & $\begin{array}{l}0.057^{* *} \\
(0.019)\end{array}$ \\
\hline Employees & $\begin{array}{l}0.000^{* * *} \\
(0.000)\end{array}$ & $\begin{array}{c}-0.001^{* * *} \\
(0.000)\end{array}$ & $\begin{array}{l}-0.001^{* *} \\
(0.000)\end{array}$ & $\begin{array}{c}-0.002^{* * *} \\
(0.000)\end{array}$ \\
\hline Full-time & $\begin{array}{l}0.459^{* * *} \\
(0.003)\end{array}$ & $\begin{array}{l}0.502^{* * *} \\
(0.016)\end{array}$ & $\begin{array}{l}0.502^{* * *} \\
(0.016)\end{array}$ & $\begin{array}{c}0.420^{* * * *} \\
(0.049)\end{array}$ \\
\hline Salaried empl. & $\begin{array}{c}-0.284^{* * *} \\
(0.002)\end{array}$ & $\begin{array}{c}-0.212^{* * * *} \\
(0.010)\end{array}$ & $\begin{array}{c}-0.214^{* * *} \\
(0.011)\end{array}$ & $\begin{array}{c}-0.117^{* *} \\
(0.041)\end{array}$ \\
\hline Spouse & $\begin{array}{l}-0.006^{* *} \\
(0.002)\end{array}$ & $\begin{array}{l}-0.012 \\
(0.010)\end{array}$ & $\begin{array}{l}-0.012 \\
(0.010)\end{array}$ & $\begin{array}{c}0.000 \\
(0.010)\end{array}$ \\
\hline Female & $\begin{array}{l}0.349^{* * *} \\
(0.002)\end{array}$ & $\begin{array}{l}0.347^{* * * *} \\
(0.009)\end{array}$ & $\begin{array}{c}0.347^{* * *} \\
(0.009)\end{array}$ & $\begin{array}{l}0.327^{* * *} \\
(0.022)\end{array}$ \\
\hline year_2 & $\begin{array}{l}0.041^{* * *} \\
(0.002)\end{array}$ & $\begin{array}{c}0.016 \\
(0.012)\end{array}$ & $\begin{array}{c}0.017 \\
(0.012)\end{array}$ & $\begin{array}{l}-0.002 \\
(0.013)\end{array}$ \\
\hline year_3 & $\begin{array}{l}0.062^{* * *} \\
(0.002)\end{array}$ & $\begin{array}{l}0.048^{* * *} \\
(0.012)\end{array}$ & $\begin{array}{c}0.048^{* * * *} \\
(0.012)\end{array}$ & $\begin{array}{l}0.029^{*} \\
(0.014)\end{array}$ \\
\hline year_4 & $\begin{array}{l}0.100^{* * *} \\
(0.002)\end{array}$ & $\begin{array}{l}0.086^{* * * *} \\
(0.012)\end{array}$ & $\begin{array}{c}0.085^{* * *} \\
(0.012)\end{array}$ & $\begin{array}{l}0.086^{* * *} \\
(0.011)\end{array}$ \\
\hline stil_2 & $\begin{array}{c}-0.120^{* * * *} \\
(0.008)\end{array}$ & $\begin{array}{c}-0.158^{* * *} \\
(0.033)\end{array}$ & $\begin{array}{c}-0.157^{* * *} \\
(0.033)\end{array}$ & $\begin{array}{c}-0.151^{* * * *} \\
(0.031)\end{array}$ \\
\hline stil_3 & $\begin{array}{c}-0.065^{* * *} \\
(0.005)\end{array}$ & $\begin{array}{l}-0.008 \\
(0.028)\end{array}$ & $\begin{array}{l}-0.010 \\
(0.029)\end{array}$ & $\begin{array}{l}0.076^{*} \\
(0.039)\end{array}$ \\
\hline stil_4 & $\begin{array}{c}0.017^{* * *} \\
(0.004)\end{array}$ & $\begin{array}{c}0.005 \\
(0.020)\end{array}$ & $\begin{array}{c}0.003 \\
(0.021)\end{array}$ & $\begin{array}{l}0.076^{*} \\
(0.030)\end{array}$ \\
\hline stil_5 & $\begin{array}{l}0.088^{* * *} \\
(0.003)\end{array}$ & $\begin{array}{l}0.069^{* * *} \\
(0.016)\end{array}$ & $\begin{array}{l}0.069^{* * *} \\
(0.016)\end{array}$ & $\begin{array}{c}0.061^{* * *} \\
(0.015)\end{array}$ \\
\hline stil_6 & $\begin{array}{c}0.118^{* * *} \\
(0.004)\end{array}$ & $\begin{array}{l}0.113^{* * *} \\
(0.019)\end{array}$ & $\begin{array}{c}0.113^{* * *} \\
(0.019)\end{array}$ & $\begin{array}{c}0.112^{* * *} \\
(0.018)\end{array}$ \\
\hline stil_7 & $\begin{array}{c}-0.201^{* * * *} \\
(0.004)\end{array}$ & $\begin{array}{c}-0.219^{* * * *} \\
(0.019)\end{array}$ & $\begin{array}{c}-0.221^{* * * *} \\
(0.020)\end{array}$ & $\begin{array}{c}-0.128^{* *} \\
(0.043)\end{array}$ \\
\hline
\end{tabular}




$\begin{array}{lcccc}\text { stil_8 } & -0.611^{* * *} & -0.640^{* * *} & -0.641^{* * *} & -0.526^{* * *} \\ & (0.007) & (0.035) & (0.035) & (0.071) \\ \text { diffwage } & & & 0.000^{* * *} \\ & & & & (0.000) \\ \text { Diffwage*elig } & & & -0.000 \\ & & & \\ \text { _cons } & -2.268^{* * *} & -2.279^{* * *} & -2.270^{* * *} & -2.327^{* * *} \\ & (0.006) & (0.031) & (0.038) & (0.081)\end{array}$

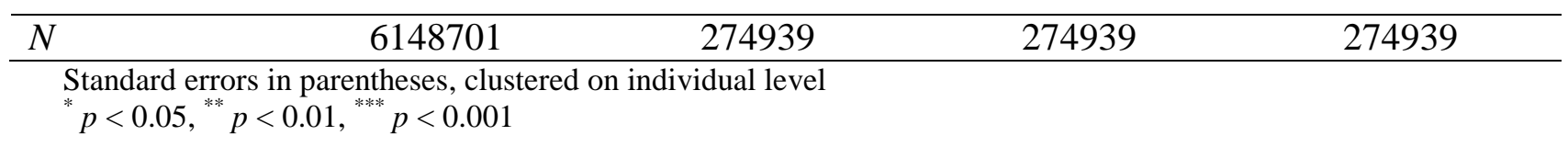


Table 7: Effects of characteristics on propensity to be sick more than 2 weeks, coefficients estimated using a probit model, controlled for time trend

(1)

Full sample
(2) Marginal firms
(3)

Marginal- IV
(4)

Marginal - IV

\begin{tabular}{lcccc}
\hline \multirow{2}{*}{ Insured } & $0.288^{* * *}$ & $0.333^{* * *}$ & $0.518^{* * *}$ & $0.323^{* * *}$ \\
& $(0.002)$ & $(0.009)$ & $(0.072)$ & $(0.055)$ \\
year_2 & $0.033^{* * *}$ & 0.003 & 0.001 & -0.002 \\
& $(0.00)^{* *}$ & $(0.011)$ & $(0.011)$ & $(0.001)$ \\
year_3 & $0.040^{* * *}$ & 0.022 & 0.021 & 0.001 \\
& $(0.002)$ & $(0.011)$ & $(0.011)$ & $(0.001)$ \\
year_4 & $0.064^{* * *}$ & $0.043^{* * *}$ & $0.047^{* * *}$ & $0.010^{* * *}$ \\
Diffwage & $(0.002)$ & $(0.011)$ & $(0.011)$ & $(0.002)$ \\
& & & & $0.000^{* * *}$ \\
Diffwageeligi & & & & $0.000)$ \\
ble & & & & 0.000 \\
& & & -1.740 & $(0.000)$ \\
_cons & & $-1.709^{* * * *}$ & $(0.013)$ & $(0.010)$ \\
& $(0.002)$ & $(0.008)$ & & $2792^{* * *}$ \\
\hline$N$ & 6268008 & 279325 & 279325 & \\
\hline
\end{tabular}

Standard errors in parentheses, clustered on individual level ${ }^{*} p<0.05,{ }^{* *} p<0.01,{ }^{* * *} p<0.001$ 
Table 8: Test of equality of sickness absence for eligible and ineligible non-participants for different bandwidth around the eligibility threshold

\begin{tabular}{|c|c|c|c|}
\hline & $\begin{array}{c}(+-1000000) \\
\text { sickness14 }\end{array}$ & $\begin{array}{l}(+-700000) \\
\text { sickness14 }\end{array}$ & $\begin{array}{c}+-1200000) \\
\text { sickness14 }\end{array}$ \\
\hline Eligible & $\begin{array}{c}-0.001 \\
(0.001)\end{array}$ & $\begin{array}{c}0.001 \\
(0.001)\end{array}$ & $\begin{array}{c}-0.001 \\
(0.001)\end{array}$ \\
\hline Age & $\begin{array}{l}0.000^{* * *} \\
(0.000)\end{array}$ & $\begin{array}{l}0.000^{* * *} \\
(0.000)\end{array}$ & $\begin{array}{l}0.000^{* * *} \\
(0.000)\end{array}$ \\
\hline children_1 & $\begin{array}{l}0.180^{* * *} \\
(0.005)\end{array}$ & $\begin{array}{l}0.181^{* * *} \\
(0.006)\end{array}$ & $\begin{array}{l}0.183^{* * *} \\
(0.005)\end{array}$ \\
\hline children_3 & $\begin{array}{c}-0.044^{* * *} \\
(0.002)\end{array}$ & $\begin{array}{c}-0.043^{* * *} \\
(0.002)\end{array}$ & $\begin{array}{c}-0.044^{* * *} \\
(0.002)\end{array}$ \\
\hline Primary & $\begin{array}{l}0.010^{* * *} \\
(0.001)\end{array}$ & $\begin{array}{l}0.010^{* * *} \\
(0.001)\end{array}$ & $\begin{array}{l}0.010^{* * *} \\
(0.001)\end{array}$ \\
\hline vocational & $\begin{array}{l}0.008^{* * *} \\
(0.001)\end{array}$ & $\begin{array}{l}0.008^{* * *} \\
(0.002)\end{array}$ & $\begin{array}{l}0.008^{* * *} \\
(0.001)\end{array}$ \\
\hline Higher & $\begin{array}{l}0.004^{*} \\
(0.002)\end{array}$ & $\begin{array}{c}0.003 \\
(0.002)\end{array}$ & $\begin{array}{c}0.004^{*} \\
(0.002)\end{array}$ \\
\hline employees & $\begin{array}{l}-0.000 \\
(0.000)\end{array}$ & $\begin{array}{l}-0.000^{* *} \\
(0.000)\end{array}$ & $\begin{array}{l}-0.000^{* *} \\
(0.000)\end{array}$ \\
\hline Fulltime & $\begin{array}{l}0.028^{* * *} \\
(0.001)\end{array}$ & $\begin{array}{c}0.028^{* * *} \\
(0.001)\end{array}$ & $\begin{array}{c}0.028^{* * *} \\
(0.001)\end{array}$ \\
\hline Salaried_empl & $-0.022^{* * *}$ & $-0.024^{* * *}$ & $-0.023^{* * *}$ \\
\hline & $(0.001)$ & $(0.002)$ & $(0.001)$ \\
\hline Spouse & $\begin{array}{c}0.001 \\
(0.001)\end{array}$ & $\begin{array}{c}0.002 \\
(0.001)\end{array}$ & $\begin{array}{c}0.001 \\
(0.001)\end{array}$ \\
\hline female & $\begin{array}{l}0.042^{* * *} \\
(0.001)\end{array}$ & $\begin{array}{l}0.041^{* * *} \\
(0.001)\end{array}$ & $\begin{array}{l}0.042^{* * *} \\
(0.001)\end{array}$ \\
\hline industry_2 & $\begin{array}{c}0.005 \\
(0.003)\end{array}$ & $\begin{array}{c}0.003 \\
(0.004)\end{array}$ & $\begin{array}{c}0.003 \\
(0.003)\end{array}$ \\
\hline industry_3 & $\begin{array}{l}-0.006 \\
(0.008)\end{array}$ & $\begin{array}{l}-0.009 \\
(0.009)\end{array}$ & $\begin{array}{l}-0.001 \\
(0.008)\end{array}$ \\
\hline industry_4 & $\begin{array}{c}0.006 \\
(0.003)\end{array}$ & $\begin{array}{c}0.003 \\
(0.004)\end{array}$ & $\begin{array}{c}0.006 \\
(0.003)\end{array}$ \\
\hline industry_5 & $\begin{array}{l}-0.000 \\
(0.003)\end{array}$ & $\begin{array}{l}-0.000 \\
(0.004)\end{array}$ & $\begin{array}{l}-0.001 \\
(0.003)\end{array}$ \\
\hline industry_6 & $\begin{array}{c}0.005 \\
(0.003)\end{array}$ & $\begin{array}{c}0.004 \\
(0.004)\end{array}$ & $\begin{array}{c}0.004 \\
(0.003)\end{array}$ \\
\hline industry_7 & $\begin{array}{l}-0.003 \\
(0.003)\end{array}$ & $\begin{array}{l}-0.003 \\
(0.004)\end{array}$ & $\begin{array}{l}-0.003 \\
(0.003)\end{array}$ \\
\hline industry_8 & $\begin{array}{c}0.002 \\
(0.004)\end{array}$ & $\begin{array}{c}0.001 \\
(0.004)\end{array}$ & $\begin{array}{c}0.001 \\
(0.003)\end{array}$ \\
\hline o.industry_9 & $\begin{array}{l}0.000 \\
(.)\end{array}$ & $\begin{array}{c}0.000 \\
(.)\end{array}$ & $\begin{array}{l}0.000 \\
(.)\end{array}$ \\
\hline year_2 & $\begin{array}{c}0.000 \\
(0.001)\end{array}$ & $\begin{array}{c}0.000 \\
(0.001)\end{array}$ & $\begin{array}{c}0.000 \\
(0.001)\end{array}$ \\
\hline
\end{tabular}




\begin{tabular}{|c|c|c|c|}
\hline year_3 & $\begin{array}{c}0.003^{*} \\
(0.001)\end{array}$ & $\begin{array}{c}0.002 \\
(0.001)\end{array}$ & $\begin{array}{c}0.003^{*} \\
(0.001)\end{array}$ \\
\hline year_4 & $\begin{array}{c}0.006^{* * *} \\
(0.001)\end{array}$ & $\begin{array}{l}0.005^{* * *} \\
(0.001)\end{array}$ & $\begin{array}{c}0.006^{* * *} \\
(0.001)\end{array}$ \\
\hline stil_2 & $\begin{array}{c}-0.020^{* * *} \\
(0.002)\end{array}$ & $\begin{array}{c}-0.017^{* * *} \\
(0.002)\end{array}$ & $\begin{array}{c}-0.020^{* * * *} \\
(0.002)\end{array}$ \\
\hline stil_3 & $\begin{array}{l}-0.001 \\
(0.002)\end{array}$ & $\begin{array}{c}0.002 \\
(0.003)\end{array}$ & $\begin{array}{c}-0.002 \\
(0.002)\end{array}$ \\
\hline stil_4 & $\begin{array}{l}-0.002 \\
(0.002)\end{array}$ & $\begin{array}{l}-0.002 \\
(0.002)\end{array}$ & $\begin{array}{l}-0.003 \\
(0.002)\end{array}$ \\
\hline stil_5 & $\begin{array}{l}0.005^{* * *} \\
(0.002)\end{array}$ & $\begin{array}{c}0.008^{* * *} \\
(0.002)\end{array}$ & $\begin{array}{c}0.005^{* * *} \\
(0.001)\end{array}$ \\
\hline stil_6 & $\begin{array}{l}0.014^{* * *} \\
(0.002)\end{array}$ & $\begin{array}{c}0.015^{* * *} \\
(0.003)\end{array}$ & $\begin{array}{c}0.013^{* * * *} \\
(0.002)\end{array}$ \\
\hline stil_7 & $\begin{array}{c}-0.009^{* * *} \\
(0.001)\end{array}$ & $\begin{array}{c}-0.007^{* * *} \\
(0.002)\end{array}$ & $\begin{array}{c}-0.010^{* * * *} \\
(0.001)\end{array}$ \\
\hline stil_8 & $\begin{array}{c}-0.033^{* * *} \\
(0.002)\end{array}$ & $\begin{array}{c}-0.030^{* * *} \\
(0.002)\end{array}$ & $\begin{array}{c}-0.033^{* * * *} \\
(0.002)\end{array}$ \\
\hline region_2 & $\begin{array}{c}-0.007^{* * *} \\
(0.001)\end{array}$ & $\begin{array}{c}-0.007^{* * *} \\
(0.001)\end{array}$ & $\begin{array}{c}-0.006^{* * *} \\
(0.001)\end{array}$ \\
\hline region_3 & $\begin{array}{c}0.001 \\
(0.002)\end{array}$ & $\begin{array}{c}0.002 \\
(0.002)\end{array}$ & $\begin{array}{c}0.001 \\
(0.002)\end{array}$ \\
\hline region_4 & $\begin{array}{l}-0.003^{*} \\
(0.001)\end{array}$ & $\begin{array}{l}-0.005^{* *} \\
(0.002)\end{array}$ & $\begin{array}{l}-0.002 \\
(0.001)\end{array}$ \\
\hline region_5 & $\begin{array}{l}-0.003^{*} \\
(0.002)\end{array}$ & $\begin{array}{l}-0.003 \\
(0.002)\end{array}$ & $\begin{array}{l}-0.003^{*} \\
(0.001)\end{array}$ \\
\hline oldprop & $\begin{array}{l}-0.003 \\
(0.004)\end{array}$ & $\begin{array}{l}-0.002 \\
(0.005)\end{array}$ & $\begin{array}{c}-0.004 \\
(0.003)\end{array}$ \\
\hline higheducpr & $\begin{array}{c}-0.018^{* * *} \\
(0.004)\end{array}$ & $\begin{array}{c}-0.021^{* * *} \\
(0.005)\end{array}$ & $\begin{array}{c}-0.018^{* * *} \\
(0.004)\end{array}$ \\
\hline femaleprop & $\begin{array}{c}0.011^{* * *} \\
(0.003)\end{array}$ & $\begin{array}{c}0.016^{* * *} \\
(0.003)\end{array}$ & $\begin{array}{c}0.010^{* * *} \\
(0.002)\end{array}$ \\
\hline _cons & $\begin{array}{l}0.009^{*} \\
(0.004)\end{array}$ & $\begin{array}{c}0.009 \\
(0.005)\end{array}$ & $\begin{array}{l}0.012^{* *} \\
(0.004)\end{array}$ \\
\hline$N$ & 223795 & 158404 & 266543 \\
\hline
\end{tabular}

